\title{
Analisis Risiko Keselamatan dan Kesehatan Kerja Menggunakan Metode Hazard and Operability Study (HAZOP) : Studi Kasus PT. Nusa Palapa Gemilang
}

\author{
Sarah Putri Aprilia ${ }^{1)}$, Bambang Suhardi*2), Rahmaniyah Dwi Astuti ${ }^{3)}$, dan Iksan Adiasa ${ }^{4)}$ \\ ${ }^{1,2,3)}$ Teknik Industri, Fakultas Teknik, Universitas Sebelas Maret, \\ Jl. Ir. Sutami No.36 A, Surakarta, 57126, Indonesia \\ ${ }^{4)}$ Teknik Industri, Fakultas Teknik, Universitas Teknologi Sumbawa, \\ Jl. Raya Olat Maras, Kabupaten Sumbawa, Nusa Tenggara Barat. 84371, Indonesia
}

\section{DOI: 10.20961/performa.19.1.39385}

\begin{abstract}
Abstrak
PT. Nusa Palapa Gemilang merupakan sebuah perusahaan yang bergerak di industri pupuk NPK dan non NPK. Berdasarkan hasil observasi didapatkan beberapa potensi bahaya kerja, salah satunya adalah karena kurangnya kesadaran pekerja mengenai keselamatan dan kesehatan kerja (K3). Penelitian ini bertujuan untuk mengidentifikasi potensi kerja untuk mengantisipasi kecelakaan kerja. Penelitian ini menggunakan Hazard and Operability Study (HAZOP) untuk menganalisis potensi hazard di unit produksi NPK 1. Berdasarkan klasifikasi hazard setelah dilakukan penilaian risiko, hasil penilaian risiko menunjukkan sebanyak 95\% potensi hazard merupakan hazard tingkat risiko tinggi (high) dan sebanyak 5\% potensi Hazard merupakan hazard risiko sedang (moderate). Selain itu, ditemukan sebanyak 14 potensi hazard yang dapat diklasifikasikan menjadi empat tipe hazard yaitu sikap kerja, prosedur kerja, tempat kerja, dan kondisi lingkungan kerja. Rekomendasi yang diberikan berdasarkan klasifikasi bahaya berupa himbauan pekerja untuk menggunakan APD berupa masker, helmet, safety spectacles, dan sepatu safety. Selain itu, diperlukan rambu-rambu seperti rambu wajib penggunaan APD, rambu bahaya forklif, dan rambu lantai licin sebagai peringatan kepada pekerja bahwa terdapat risiko bahaya saat berada di tempat kerja, sehingga K3 di tempat kerja dapat ditingkatkan dan dapat memiminimalkan kecelakaan kerja.
\end{abstract}

Kata kunci: kecelakaan kerja, HAZOP, risk assessment

\begin{abstract}
PT. Nusa Palapa Gemilang is a company engaged in the NPK and Non-NPK fertilizer industries. Based on observations obtained several potential occupational hazards, one of which is due to the lack of awareness of workers regarding occupational safety and health (K3). This study aims to identify the work potential to anticipate work accidents. This study used a Hazard and Operability Study (HAZOP) to analyze the potential hazards in NPK production units 1. Based on the hazard classification after a risk assessment, the risk assessment results show that as many as $95 \%$ of potential hazards are high-risk levels and 5\% potential hazard is a moderate risk hazard. Besides, 14 potential hazards could be classified into four types of hazards, namely work attitudes, work procedures, workplaces, and work environment. Recommendations are given based on hazard classifications in the form of workers' advice to use PPE in the form of masks, helmets, safety glasses and safety shoes. In addition, signs are also required such as mandatory PPE signs, forklift hazard signs and slippery floor signs to warn workers of risks during work, so that $K 3$ in the workplace can be improved and can reduce work accidents.
\end{abstract}

Keywords: work accident, HAZOP, risk assessment

\section{Pendahuluan}

Persaingan industri yang sangat kompetitif pada era globalisasi khususnya dalam era Masyarakat Ekonomi ASEAN (MEA) membuat sumber daya manusia menjadi aspek terpenting sehingga aset perusahaan atau human invesment harus lebih diperhatikan mengingat adanya ancaman bahaya (hazard) potensial yang berhubungan dengan kerja. Data dari Badan Penyelenggara Jaminan Sosial

*Korespondensi: bambangsuhardi@staff.uns.ac.id 
(BPJS) Ketenagakerjaan mencatat pada tahun 2017 telah terjadi kecelakaan kerja sebanyak 123.041 kasus dan meningkat pada tahun 2018 sebanyak 173.105 kasus (BPJS Ketenagakerjaan, 2019).

Tarwaka (2008) mendefinisikan kecelakaan kerja sebagai suatu kejadian yang tidak dikehendaki dan sering kali tidak terduga yang dapat menimbulkan kerugian baik waktu, harta benda atau properti maupun korban jiwa yang terjadi di dalam suatu proses kerja industri atau yang berkaitan dengannya. Keselamatan dan kesehatan kerja (K3) telah diatur oleh Undang-undang Nomor 1 Tahun 1970 tentang pelaksanaan K3 di semua tempat.

Adanya peristiwa kecelakaan dapat merugikan perusahaan dari segi biaya langsung (direct cost) seperti biaya kompensasi pembayaran asuransi kecelakaan dan biaya tidak langsung (indirect cost) seperti hilangnya waktu kerja dan terhentinya proses produksi sementara (Hartoyo dkk, 2015).

PT. Nusa Palapa Gemilang merupakan perusahaan yang begerak di bidang pembuatan pupuk NPK dan non-NPK. Proses produksi pupuk NPK melewati beberapa tahap yaitu dimulai dari bahan baku, granulasi (granulator), pengeringan granule (dryer), pemisahan granulasi berdasarkan ukuran (screening I), pemberian warna dan anti-caking (screening II), pencampuran warna dan anti-caking (coating), dan pengemasan (bagging). Perusahaan ini menargetkan hasil produksi 210 ton per hari dengan pekerja di unit produksi 1 sebanyak 60 orang.

Penelitian ini dilakukan pada unit NPK 1 dikarenakan hasil observasi menunjukkan bahwa terdapat beberapa potensi bahaya, seperti tidak adanya rambu-rambu untuk forklift yang dapat membahayakan pekerja yang melewatinya jika tidak berhati-hati. Risiko yang mungkin terjadi adalah pekerja dapat tertabrak forklift.

Berdasarkan wawancara dengan pekerja, beberapa kecelakaan kerja pernah dialami pekerja salah satunya adalah pekerja terpeleset akibat dari pupuk yang terkena air hujan sehingga lantai menjadi licin dan kepala tebentur mesin dryer.

Kurangnya tingkat kesadaran pekerja menggunakan alat pelindung diri (APD) seperti memakai masker dan sepatu safety sehingga mengakibatkan risiko tinggi yang dapat membahyakan keselamatan dan kesehatan pekerja. Hal ini didukung dengan data kecelakaan kerja pada periode 2017-2018 tercatat sebanyak 27 pekerja mengalami kecelakaan kerja. Salah satunya terjadi dikarenakan tidak terdapatnya departemen khusus yang menangani K3 sehingga kurangnya kesadaran dan pengetahuan pekerja terkait dengan $\mathrm{K} 3$.

Penelitian terdahulu terkait dengan K3 yaitu penelitian Suhardi dkk (2018) menggunakan metode Hazard Identification Risk Assesment (HIRA) dan HAZOP di industri pembuatan batik. Hasil penelitian ini ditemukan terdapat 17 potensi hazard di area produksi batik printing. Restuputri dan Sari (2015) menggunakan Hazard and Operability Study (HAZOP) pada pembuatan pengaman kaca (safety glass). Hasil penelitian ini diperoleh 9 sumber potensi bahaya. Pujino dkk (2013) menggunakan metode HAZOP di industri kertas. Hasil penelitian ini ditemukan 43 potensi hazard. Fattor dan Vieira (2019) menggunakan Preliminary Risk Analysisi (PRA) dan Hazard and Operability Study (HAZOP) di pengolahan limbah Hasil PRA pada pre-screening munjukkan risiko tinggi dikarenakan belum adanya pengetahuan mendalam tentang bahan daur ulang yang dapat mnyebabkan risiko tinggi seperti kontak dengan material kimia dan biologi. Selain itu juga, risiko kecelakaan dapat terjadi seperti pekerja terkena pecahan kaca. Hasil HAZOP menunjukkan risiko tertinggi yaitu di penerimaan material dan pre-screening.

Berdasarkan hal tersebut, dengan adanya potensi hazard yang muncul, diperlukan manajemen risiko yang meliputi identifikasi hazard untuk mengetahui risiko yang menimbulkan bahaya kecelakaan kerja, analisis potensi hazard, penilaian risiko, dan membuat suatu rekomendasi guna mengurangi terjadinya kecelakaan kerja. Sehingga perlu dilakukan penelitian lebih lanjut untuk mengidentifikasi dan usulan perbaikan kondisi kerja untuk meminimalisasi bahaya Penelitian ini menggunakan Hazard and Operability Study (HAZOP), yaitu suatu metode yang digunakan untuk mengidentifikasi dan menganalisis hazard sehingga proses yang berlangsung dalam suatu sistem dapat berjalan dengan lancar dan aman (Juniani dkk, 2008). 


\section{Metode Penelitian}

Metode HAZOP digunakan dalam menganalisis potensi bahaya di PT. Nusa Palapa Gemilang unit produksi NPK 1. Menurut Kletz (1999), metode HAZOP digunakan untuk mengidentifikasi bahaya yang mencegah operasi berjalan secara efisien dan memutuskan usulan perbaikan apa yang harus dilakukan.

Pengumpulan data primer diperoleh berupa gambaran bahaya dan risiko dengan cara melakukan observasi terhadap mesin yang digunakan, kondisi tempat kerja dan tahapan proses yang dilakukan terkait dengan proses produksi. Observasi dilakukan dengan melihat kondisi tempat kerja dan mesin yang digunakan serta mencatat tahapan proses yang dilakukan di lapangan.

Selain itu juga wawancara dilakukan terhadap koordinator produksi, manager pabrik, dan beberapa pekerja yang ada pada area produksi. Sedangkan pengumpulan data sekunder diperoleh dari data perusahaan yaitu layout perusahaan, data kecelakaan kerja, dan SOP.

Langkah-langkah dalam melakukan pengumpulan dan pengolahan data sebagai berikut:

1. Melakukan identifikasi hazard

Sebelum dilakukan identifikasi hazard, identifikasi penyimpangan proses produksi dibutuhkan untuk mengidentifikasi penyimpangan yang ada selama proses produksi berlangsung. Identifikasi dilakukan dengan langkah-langkah sebagai berikut:

a) Menentukan lokasi yang akan di observasi. Dalam penelitian ini dilakukan observasi pada unit produksi NPK 1.

b) Untuk setiap lokasi, dilakukan observasi proses produksi dari awal sampai akhir dan juga melakukan observasi terhadap pekerja yang melakukan unsafe act

c) Menentukan penyimpangan yang ada dilihat dari proses produksi dan instruksi kerja berupa SOP, data kecelakaan kerja, dan unsafe act.

2. Penilaian risiko

Dilakukan berdasarkan tabel identifikasi risiko. Penilaian risiko ini digunakan untuk mengetahui potensi hazard pada setiap area kerja di unit produksi NPK 1. Berikut ini merupakan penilaian level risiko yang mengacu pada Australian standard/ New Zealand Standard (AS/NZS) 4360:1999:

Tabel 1. Penilaian Level Risiko

\begin{tabular}{|l|l|l|l|l|l|l|}
\hline \multicolumn{2}{|c|}{} & \multicolumn{6}{|c|}{\begin{tabular}{c} 
Consequence \\
\cline { 3 - 8 } \multicolumn{2}{|c|}{}
\end{tabular}} & $\begin{array}{c}\text { Insignificant } \\
(1)\end{array}$ & $\begin{array}{c}\text { Minor } \\
(2)\end{array}$ & $\begin{array}{c}\text { Moderate } \\
(3)\end{array}$ & $\begin{array}{c}\text { Major } \\
(4)\end{array}$ & $\begin{array}{c}\text { Catastrophic } \\
(5)\end{array}$ \\
\hline \multirow{3}{*}{ Likelihood } & Almost certain (A) & A1 & A2 & A3 & A4 & A5 \\
\cline { 2 - 8 } & Likely $(B)$ & B1 & B2 & B3 & B4 & B5 \\
\cline { 2 - 8 } & Possible $(C)$ & C1 & C2 & C3 & C4 & C5 \\
\cline { 2 - 8 } & Unlikely (D) & D1 & D2 & D3 & D4 & D5 \\
\cline { 2 - 8 } & Catastrophic $(E)$ & E1 & E2 & E3 & E4 & E5 \\
\hline
\end{tabular}

Keterangan :

Tabel 2. Indikator Level Risiko

\begin{tabular}{|c|c|l|}
\hline \multicolumn{2}{|c|}{ Risk Level } & \multicolumn{1}{c|}{ Deskripsi } \\
\hline & Extreme Risk & Sangat Berisiko, dibutuhkan tindakan secepatnya \\
\hline & High Risk & Berisiko Besar, dibutuhkan perhatian dari manajemen puncak \\
\hline Moderate Risk & Risiko sedang, tanggung jawab manajemen harus spesifik \\
\hline & Low Risk & Risiko rendah, ditangani dengan prosedur rutin \\
\hline
\end{tabular}

Skor Level risiko = likelihood $\mathrm{x}$ consequence

3. Klasifikasi hazard berdasarkan sumbernya

Sumber hazard diklasifikasikan berdasarkan sikap kerja, prosedur kerja, tempat kerja, dan lingkungan kerja (Suhardi dkk, 2018). 
4. HAZOP worksheet

HAZOP worksheet meliputi penyimpangan (deviation), penyebab penyimpangan (cause), akibat dari penyimpangan (consequence), dan rekomendasi usulan tindakan perbaikan (action) (Kurniawati dkk, 2014).

\section{Hasil dan Pembahasan}

Metode HAZOP digunakan dalam penelitian di unit produksi NPK 1. Tabel 3 merupakan data identifikasi dan penilaian risiko melalui observasi lapangan secara langsung dan wawancara untuk memperoleh temuan potensi hazard.

Tabel 3. Identifikasi Potensi Hazard Unit Produksi NPK

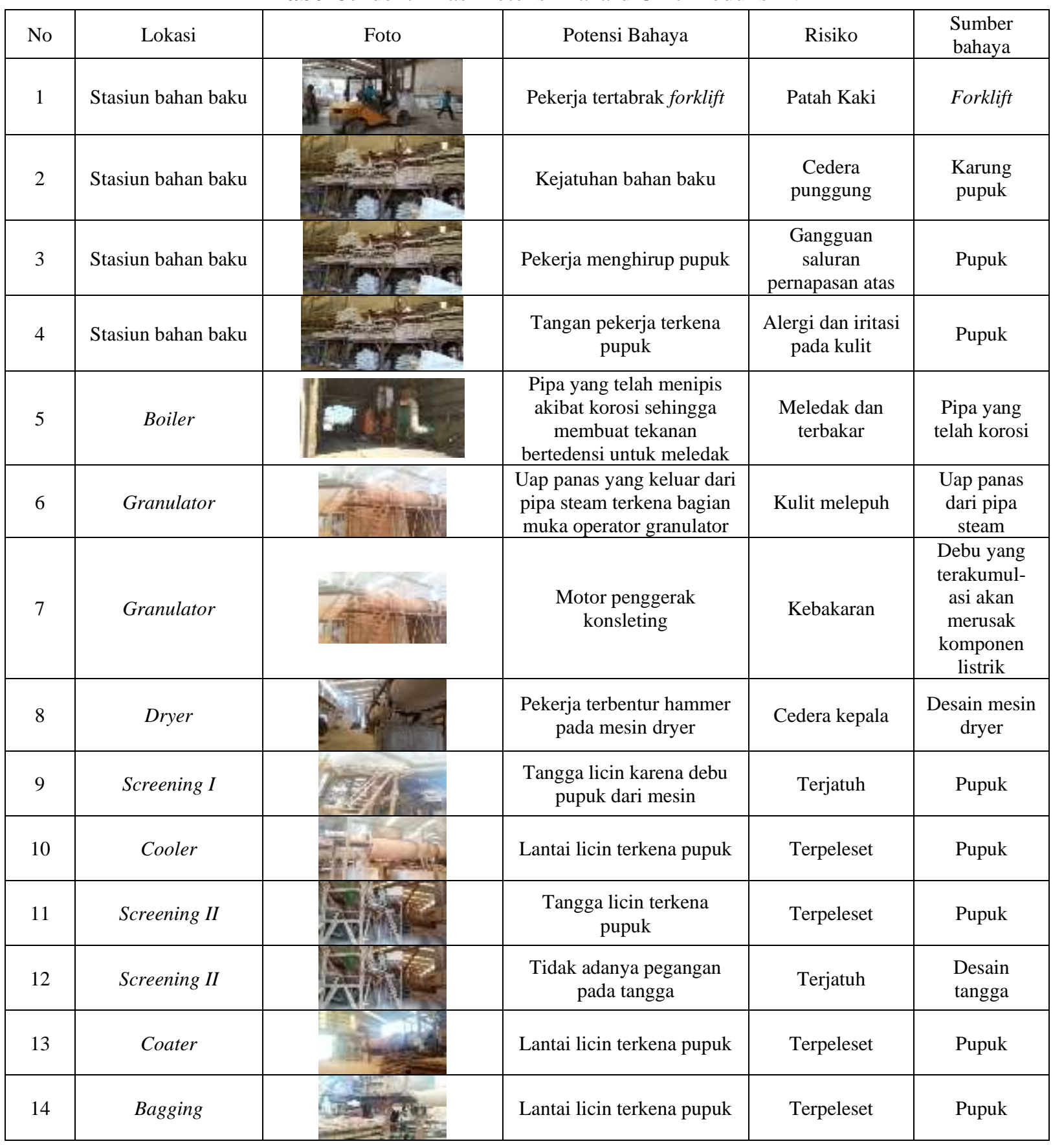

Penilaian risiko digunakan untuk mengetahui potensi hazard pada setiap area kerja di unit produksi NPK 1. Proses rekapitulasi potensi bahaya dilakukan dengan menentukan level risiko. Likelihood ( $($ ) merupakan tingkat kemungkinan terjadinya kecelakaan dan Consequence (c) merupakan dampak akibat dari suatu kejadian. Penilaian likelihood dan consequence mengacu pada AS/NZS 4360:1999. Secara lengkap contoh penilaian risiko yang ada pada stasiun bahan baku di unit produksi NPK 1 dapat dilihat pada Tabel 4 menggunakan rumus (1).

Level risiko $=$ likelihood $\mathrm{x}$ consequence 
Tabel 4. Contoh Penilaian Tingkat Risiko

\begin{tabular}{|c|c|c|c|c|c|c|c|c|c|}
\hline No & Lokasi & Foto & Potensi Bahaya & Risiko & $\begin{array}{c}\text { Sumber } \\
\text { bahaya }\end{array}$ & L & C & S & Risk Level \\
\hline 1 & $\begin{array}{c}\text { Stasiun } \\
\text { bahan baku }\end{array}$ & Pिi & $\begin{array}{c}\text { Pekerja tertabrak } \\
\text { forklift }\end{array}$ & Patah kaki & Forklift & E & 3 & E3 & Moderate \\
\hline
\end{tabular}

Berikut ini merupakan penilaian risiko unit produksi NPK 1 dapat dilihat pada Tabel 5:

Tabel 5. Identifikasi Hazard Unit Produksi NPK 1

\begin{tabular}{|c|c|c|c|c|c|c|c|c|c|}
\hline No & Lokasi & Foto & Potensi Bahaya & Risiko & $\begin{array}{l}\text { Sumber } \\
\text { bahaya }\end{array}$ & $\mathrm{L}$ & C & $\mathrm{S}$ & $\begin{array}{l}\text { Risk } \\
\text { Level }\end{array}$ \\
\hline 1 & $\begin{array}{c}\text { Stasiun } \\
\text { bahan baku }\end{array}$ & $1,1, y=A$ & $\begin{array}{l}\text { Pekerja tertabrak } \\
\text { forklift }\end{array}$ & Patah Kaki & Forklift & E & 3 & E3 & Moderate \\
\hline 2 & $\begin{array}{c}\text { Stasiun } \\
\text { bahan baku }\end{array}$ & & $\begin{array}{l}\text { Kejatuhan bahan } \\
\text { baku }\end{array}$ & $\begin{array}{l}\text { Cedera } \\
\text { punggung }\end{array}$ & Karung pupuk & B & 2 & B2 & High \\
\hline 3 & $\begin{array}{c}\text { Stasiun } \\
\text { bahan baku }\end{array}$ & - & $\begin{array}{c}\text { Pekerja } \\
\text { menghirup pupuk }\end{array}$ & $\begin{array}{l}\text { Gangguan } \\
\text { saluran } \\
\text { pernapasan } \\
\text { atas }\end{array}$ & Pupuk & A & 2 & A2 & High \\
\hline 4 & $\begin{array}{c}\text { Stasiun } \\
\text { bahan baku }\end{array}$ & $\frac{12}{12}$ & $\begin{array}{l}\text { Tangan pekerja } \\
\text { terkena pupuk }\end{array}$ & $\begin{array}{l}\text { Alergi dan } \\
\text { iritasi pada } \\
\text { kulit }\end{array}$ & Pupuk & A & 2 & A2 & High \\
\hline 5 & Boiler & & $\begin{array}{c}\text { Pipa yang telah } \\
\text { menipis akibat } \\
\text { korosi sehingga } \\
\text { membuat tekanan } \\
\text { bertedensi untuk } \\
\text { meledak } \\
\end{array}$ & $\begin{array}{l}\text { Meledak dan } \\
\text { terbakar }\end{array}$ & $\begin{array}{l}\text { Pipa yang } \\
\text { telah korosi }\end{array}$ & E & 5 & E5 & High \\
\hline 6 & Granulator & & $\begin{array}{c}\text { Uap panas yang } \\
\text { keluar dari pipa } \\
\text { steam terkena } \\
\text { bagian muka } \\
\text { operator } \\
\text { granulator } \\
\end{array}$ & $\begin{array}{c}\text { Kulit } \\
\text { melepuh }\end{array}$ & $\begin{array}{l}\text { Uap panas dari } \\
\text { pipa steam }\end{array}$ & A & 2 & $\mathrm{~A} 2$ & High \\
\hline 7 & Granulator & & $\begin{array}{l}\text { Motor penggerak } \\
\text { konsleting }\end{array}$ & Kebakaran & $\begin{array}{c}\text { Debu yang } \\
\text { terakumul-asi } \\
\text { akan merusak } \\
\text { komponen } \\
\text { listrik } \\
\end{array}$ & E & 4 & E4 & High \\
\hline 8 & Dryer & & $\begin{array}{c}\text { Pekerja terbentur } \\
\text { hammer pada } \\
\text { mesin dryer }\end{array}$ & $\begin{array}{l}\text { Cedera } \\
\text { kepala }\end{array}$ & $\begin{array}{l}\text { Desain mesin } \\
\quad \text { dryer }\end{array}$ & A & 2 & A2 & High \\
\hline 9 & Screening I & & $\begin{array}{c}\text { Tangga licin } \\
\text { karena debu } \\
\text { pupuk dari mesin }\end{array}$ & Terjatuh & Pupuk & A & 2 & A2 & High \\
\hline 10 & Cooler & & $\begin{array}{l}\text { Lantai licin } \\
\text { terkena pupuk }\end{array}$ & Terpeleset & Pupuk & A & 2 & A2 & High \\
\hline 11 & $\begin{array}{l}\text { Screening } \\
\text { II }\end{array}$ & & $\begin{array}{l}\text { Tangga licin } \\
\text { terkena pupuk }\end{array}$ & Terpeleset & Pupuk & A & 2 & A2 & High \\
\hline 12 & $\begin{array}{l}\text { Screening } \\
\text { II }\end{array}$ & SAp & $\begin{array}{c}\text { Tidak adanya } \\
\text { pegangan pada } \\
\text { tangga }\end{array}$ & Terjatuh & Desain tangga & A & 2 & $\mathrm{~A} 2$ & High \\
\hline 13 & Coater & & $\begin{array}{l}\text { Lantai licin } \\
\text { terkena pupuk }\end{array}$ & Terpeleset & Pupuk & A & 2 & A2 & High \\
\hline 14 & Bagging & 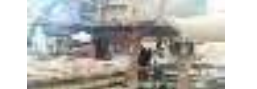 & $\begin{array}{l}\text { Lantai licin } \\
\text { terkena pupuk }\end{array}$ & Terpeleset & Pupuk & A & 2 & A2 & High \\
\hline
\end{tabular}

\section{Keterangan:}

$$
\begin{array}{ll}
\mathrm{L} & =\text { Likelihood } \\
\mathrm{C} & =\text { Consequences } \\
\mathrm{S} & =\text { Skor }
\end{array}
$$


Temuan potensi bahaya dapat dikategorikan sebagai risiko ekstrim, tinggi, sedang, dan rendah. Berdasarkan hasil yang ditemukan, 95\% bahaya termasuk dalam kategori risiko tinggi dan 5\% termasuk dalam kategori risiko sedang. Risiko tinggi memerlukan lebih lebih dari manajamen. Dapat dilihat pada Gambar. 1 risk level potensi hazard di unit produksi NPK 1 dan unit produksi non NPK.

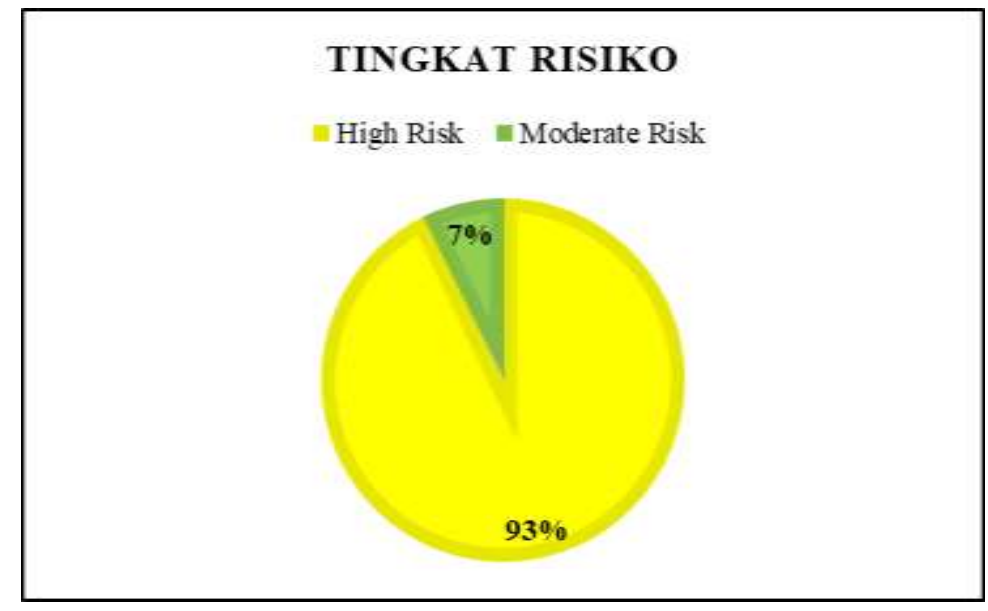

Gambar 1. Pie Chart Tingkat Risiko

Setelah dilakukan identifikasi bahaya dan penilaian risiko, kemudian potensi hazard tersebut diklasifikasikan berdasarkan sumber bahaya ditujukkan pada Tabel 6.

Tabel 6. Klasifikasi Hazard

\begin{tabular}{|c|c|c|}
\hline No. & Klasifikasi bahaya & Jumlah potensi bahaya \\
\hline 1 & $\begin{array}{c}\text { Sikap kerja } \\
(3,4,6,8)\end{array}$ & 4 \\
\hline 2 & $\begin{array}{c}\text { Prosedur kerja } \\
(1,2,5,7)\end{array}$ & 1 \\
\hline 3 & $\begin{array}{c}\text { Tempat kerja } \\
(12)\end{array}$ & 5 \\
\hline 4 & $\begin{array}{c}\text { Kondisi lingkungan kerja } \\
(9,10,11,13,14)\end{array}$ \\
\hline
\end{tabular}

Pada unit produksi NPK 1 ditemukan sebanyak 14 hazard yang diklasifikasikan menjadi 6 sumber bahaya yaitu sikap kerja terdapat 4 potensi bahaya, prosedur kerja, dan terdapat 4 potensi bahaya, tempat kerja.

Klasifikasi bahaya sikap kerja merupakan pengolompokan potensi bahaya berdasarkan kondisi tempat kerja yang kurang memadai sehingga berpotensi mengaggu aktivitas pekerja dan pekerja berpotensi mengalami kecelakaan kerja. APD adalah suatu alat yang mempunyai kemampuan untuk melindungi seseorang yang fungsinya mengisolasi sebagian atau seluruh tubuh dari potensi bahaya di tempat kerja (kemenakertrans, 2010). Pekerja/buruh dan orang lain yang memasuki tempat kerja wajib memakai atau menggunakan APD sesuai dengan potensi bahaya dan risiko (Kemenakertrans, 2010).

Pada penelitian ini, terdapat empat potensi bahaya yang termasuk ke dalam klasifikasi bahaya sikap kerja yaitu pekerja yang menghirup pupuk, tangan pekerja yang berpotensi terkena alergi dan iritasi akibat terpapar pupuk, pekerja terpapar uap panas yang keluar dari pipa steam granulator, dan pekerja tebentur hammer pada mesin dryer.

Perbaikan yang diusulkan terhadap pekerja menghirup pupuk yaitu dengan menghimbau pekerja untuk memakai masker dan rambu peringatan area wajib menggunakan masker. Usulan perbaikan untuk tangan pekerja yang terpapar pupuk yaitu dengan menghimbau pekerja untuk memakai sarung tangan, membuat rambu peringatan area bahan baku wajib menggunakan sarung tangan, dan manajemen menyediakan APD yang belum tersedia yaitu sarung tangan. Usulan perbaikan untuk pekerja yang terpapar uap panas dari pipa steam granulator yaitu dengan menghimbau pekerja memakai safety spectacles, membuat rambu peringatan wajib menggunakan safety spectacles, dan manajemen menyediakan APD yang belum tersedia yaitu safety spectacles. Usulan perbaikan untuk 
pekerja terbentur hammer pada mesin dryer yaitu dengan menghimbau pekerja menggunakan safety helmet dan membuat rambu peringatan wajib menggunakan helmet. Selain itu, perusahaan juga dapat memberikan training K3 untuk meningkatkan kesadaran pekerja akan pentingnya K3.

Klasifikasi prosedur kerja merupakan pengolompokan potensi bahaya berdasarkan yaitu pengelompokkan potensi hazard yang disebabkan oleh prosedur atau aktivitas kerja yang memiliki risiko dapat mencederai pekerja. Pada penelitian ini, terdapat empat potensi bahaya yang termasuk ke dalam klasifikasi bahaya tempat kerja yaitu potensi pekerja tertabrak forklift akibat tidak adanya rambu K3 untuk forklift, pekerja tertimpa bahan baku, pipa yang telah korosi, dan motor penggerak granulator yang berpotensi konsleting.

Perbaikan yang diusulkan terhadap potensi pekerja terabrak forklift yaitu dengan membuat rambu K3 forklift dan mempertegas batas antara pejalan kaki dan forklift. Usulan perbaikan untuk pekerja tertimpa bahan baku yaitu dengan menghimbau pekerja menggunakan helmet dan standard operational procedure (SOP) forklift untuk meletakkan bahan baku. Usulan perbaikan untuk pipa berpotensi korosi dan motor penggerak konsleting yaitu dengan mengadakan inspeksi secara rutin, melaporkan jika terdapat kerusakan pada mesin, dan perusahaan juga dapat memasang alat detektor kebakaran.

Klasifikasi bahaya tempat kerja merupakan pengolompokan potensi bahaya berdasarkan kondisi tempat kerja yang kurang memadai sehingga berpotensi mengaggu aktivitas pekerja dan pekerja berpotensi mengalami kecelakaan kerja. Pada penelitian ini, terdapat dua potensi bahaya yang termasuk ke dalam klasifikasi bahaya tempat kerja yaitu desain tangga yang tidak ergonomis.

Aktivitas pekerja yang menaiki dan menuruni tangga dengan keadaan desain tangga yang tidak ergonomis dapat berpotensi membuat pekerja terjatuh dari tangga. Perbaikan yang diusulkan yaitu dengan menghimbau pekerja untuk senantiasa menggunakan APD sepatu safety, membuat rambu peringatan area wajib menggunakan sepatu safety, dan perusahaan juga dapat mengganti desain tangga untuk meminimalisasi potensi bahaya pekerja terjatuh dari tangga.

Klasifikasi hazard berdasarkan lingkungan kerja yaitu pengelompokkan potensi hazard yang disebabkan oleh kondisi lingkungan kerja yang dapat mempengaruhi aktivitas kerja yang mengacu pada keadaan tempat kerja seperti debu, suhu, kebisingan, udara dan kualitas pencahayaan. Pada penelitian ini, terdapat lima potensi bahaya yang termasuk ke dalam klasifikasi bahaya lingkungan kerja yaitu terkait dengan tangga yang licin dan lantai yang licin jika terkena air hujan.

Perbaikan yang diusulkan yaitu dengan menghimbau pekerja untuk menggunakan sepatu safety, pengecekan dan pembersihan area yang licin secara rutin, dan membuat rambu peringatan area wajib menggunakan sepatu safety.

\section{Simpulan}

Potensi bahaya yang ada di unit produksi NPK 1 dapat digolongkan menjadi 13 potensi hazard yang berasal dari 4 klasifikasi bahaya yaitu sikap kerja, prosedur kerja, tempat kerja, dan kondisi lingkungan kerja. Risiko bahaya yang ditimbulkan pada unit produksi NPK 1 meliputi risiko sedang dan tinggi. Rekomendasi yang diberikan berdasarkan klasifikasi bahaya dengan usulan berupa himbauan pekerja untuk menggunakan APD berupa masker, helmet, safety spectacles, dan sepatu safety. Selain itu, diperlukan rambu-rambu seperti rambu wajib penggunaan APD, rambu bahaya forklif, rambu lantai licin, dsbnya sebagai peringatan kepada pekerja bahwa terdapat risiko bahaya saat berada di tempat kerja. Dengan demikian K3 di tempat kerja dapat ditingkatkan dan dapat memiminimalkan kecelakaan kerja.

\section{Daftar Pustaka}

BPJS Ketenagakerjaan. (2019). [online] https: bpjsketenagakerjaan.go.id/berita/23322/AngkaKecelakaan-Kerja-Cenderung-Meningkat,-BPJS-Ketenagakerjaan-Bayar-Santunan-Rp1,2Triliun (Diakses pada 27 oktober 2019).

Fattor, M. V., \& Vieira, M. G. A. (2019). Application of human HAZOP technique adapted to identify risks in Brazilian waste pickers' cooperatives. Journal of EnvironmentalManagement, 246, 247 258. doi: 10.1016/j.jenvman.2019.05.128. 
Hartoyo, E., Sholihah, Q., Fauzia, R., \& Rachmah, D. (2015). Sarapan Pagi \& Produktivitas. Malang: Universitas Brawijaya Press (UB Press).

Joint Standards Australia/ Standards New Zealand. AS/NZS4360:1999. Risk Management

Juniani, A., Handoko, L., \& Firmansyah, C. (2008). Implementasi Metode HAZOPS dalam Proses Identifikasi Bahaya dan Analisa Risiko pada Feedwater System di Unit Pembangkitan Paiton PT. PJB.

Kemenakertrans RI. (2010). Peraturan Menteri Tenaga Kerja dan Transmigrasi RI Nomor 8 Tahun 2010 Tentang Alap Pelindung Diri.

Kurniawati, E., Sugiono, Yuniarti, R. (2014). Analisis Potensi Kecelakaan Kerja Pada Departemen Produksi Springbed Dengan Metode Hazard Identification and Risk Assessment (HIRA) (Studi Kasus: PT. Malindo Intitama Raya, Malang, Jawa Timur). Jurnal Rekayasa dan Manajemen Sistem Industri.

Kletz, T. (1999). HAZOP and HAZAN, Taylor \& Francis group, New York.

Pujino, B. N., Tama, I. P., \& Efranto, R. Y. Analisis Potensi Bahaya Serta Rekomendasi Perbaikan dengan Metode Hazard and Operability Study (HAZOP) melalui perangkingan OHS Risk Assessment and Control (Studi kasus: Area PM-1 PT. Ekamas Fortuna). Jurnal Rekayasa dan Manajemen Sistem Industri, 1(2), 253-264.

Restuputri, D. P., \& Sari., R. P. (2015). Analisis Kecelakaan Kerja Dengan Menggunakan Metode Hazard and Operability Study (HAZOP). Jurnal Ilmiah Teknik Industri, 14(1), 24-35.

Suhardi, B., Laksono, P. W., Ayu, A., Rohani, J. M., \& Ching, T. S. (2018). Analysis of the Potential Hazard Identification and Risk Assessment (HIRA) and Hazard Operability Study (HAZOP): Case Study. International Journal of Engineering \& Technology, 7(3.24), 1-7.

Tarwaka. (2008). Keselamatan dan Kesehatan Kerja "Manajemen dan Implementasi K3 di Tempat Kerja". Surakarta: Harapan Press. 